\title{
EVALUASI PELAKSANAAN RENCANA PEMBANGUNAN JANGKA MENENGAH DAERAH (RPJMD) BIDANG URUSAN PEKERJAAN UMUM KABUPATEN KEPULAUAN ANAMBAS, PROVINSI KEPULAUAN RIAU
}

\author{
Linayati Lestari ${ }^{1}$, Dian Mustika Rini ${ }^{2}$, Nova Dwiyanti ${ }^{3}$ \\ ${ }^{1}$ Prodi Ilmu Pemerintahan, Fakultas Ilmu Sosial dan Ilmu Politik, Universitas Riau Kepulauan, Indonesia \\ linayati@fisip.unrika.ac.id \\ ${ }^{2}$ Prodi Ilmu Pemerintahan, Fakultas Ilmu Sosial \& Ilmu Politik, Universitas Riau Kepulauan, Indonesia \\ dianrini@gmail.com \\ ${ }^{3}$ Prodi Ilmu Pemerintahan, Fakultas Ilmu Sosial dan Ilmu Politik, Universitas Riau Kepulauan, Indonesia \\ novadwiyanti82@gmail.com
}

\begin{abstract}
Abstrak
Tulisan ini berisi hasil penelitian mengenai pembangunan daerah sebagai bagian intergral dari pembangunan Nasional dilaksanakan berdasarkan prinsip otonomi daerah dan pengaturan sumber daya Nasional untuk meningkatkan kesejahteraan masyarakat di Provinsi Kepulauan Riau khususnya di Kabupaten Kepulauan Anambas. Rencana Pembangunan Jangka Menengah Daerah adalah Rencana pembangunan daerah berdurasi 5 tahun yang didalamnya terdapat penjabaran visi misi pemerintahan daerah. RPJMD Kabupaten Kepulauan Anambas Tahun 2011-2015 sudah dilaksanakan sesuai dengan program-program atau kegiatan yang ditelah direncanakan oleh seluruh Organisasi Pemerintah Daerah (OPD) Kabupaten Kepulauan Anambas. Tujuan dari penelitian ini ialah mengetahui capaian dari RPJMD kepulauan Anambas di Tahun 2011-2015. Alat analisis yang digunakan adalah Efektivitas, Efisiensi, Perataan, dan Responsivitas. Metode penelitian yang digunakan adalah metode penelitian deskriptif dengan pendekatan kualitatif. Dari hasil penelitian yang dilakukan ini diperoleh kesimpulan bahwa sesuai dengan alat analisis yaitu, indikator Efektivitas, Efiensi, Kecukupan, Perataan, responsivitas dan Ketepatan rencana pembangunan jangka menengah daerah bidang urusan pekerjaan umum belum terlaksanakan sepenuhnya oleh dinas pekerjaan umum penataan ruang dan pemukiman kawasan karena kendala-kendala yang ada. Maka dapat disimpulkan dalam penelitian ini bahwa evaluasi pelaksanaan dari Rencana Pembangunan Jangka Menengah Daerah Bidang Urusan Pekerjaan Umum Kabupaten Kepulauan Anambas ini masih belum berjalan dengan semestinya karena terdapat beberapa kendala dari faktor dana yang tidak mencukupi untuk membiayai semua perencanaan, lokasi dan kondisi alam yang kurang mendukung dan juga sumber daya manusia yang masih belum cakap atas program atau kegiatan tersebut.

Kata Kunci: Evaluasi, RPJMD, Pemerintah, Pekerjaan Umum.
\end{abstract}

\begin{abstract}
This paper contains the results of research on regional development as anintegral part of national development carried out based on the principle of regional autonomy and regulation of national resources to improve the welfare of the people in the Riau Islands Province, especially in the Anambas Islands Regency. The Regional Medium Term Development Plan is a 5-year regional development plan in which there is a description of the regional government's vision and mission. Anambas Islands District RPJMD 2011-2015 has been implemented in accordance with the programs or activities that have been planned by all Anambas Islands Regional Government Organizations $(O P D)$. The purpose of this study is to find out the achievements of the Anambas Islands RPJMD in 2011-2015. The analytical tool used is Effectiveness, Efficiency, Alignment and Responsiveness. The research method used is descriptive research method with a qualitative approach. From the results of this research, it was concluded that in accordance with the analytical tool, indicators of Effectiveness, Efficiency, Adequacy, Grading, Responsiveness and Accuracy of the medium-term development plan in the field of public works affairs had not been fully implemented by the public works agency spatial planning and regional settlement due to constraints existing constraints. So it can be concluded in this study that the evaluation of the implementation of the Regional Medium Term Regional Development
\end{abstract}


Plan for Public Works Affairs of Anambas Islands Regency is still not running properly because there are some constraints from insufficient funds to finance all planning, location and natural conditions that are less supportive and also human resources who are still not capable of the program or activity.

Keywords: Evaluation, RPJMD, Government, Public Works.

\section{PENDAHULUAN}

Dengan berlakunya Undang-Undang No. 22 tahun 1999 tentang Pemerintahan Daerah dan telah diganti dengan Undang-Undang Nomor 32 Tahun 2004, penyelenggaraan otonomi daerah dilaksanakan dengan memberikan kewenangan yang luas, nyata, dan bertanggung jawab kepada daerah. Pemberian kewenangan yang luas kepada daerah memerlukan koordinasi dan pengaturan untuk lebih mengharmoniskan dan menyelaraskan pembangunan, baik pembangunan Nasional, pembangunan daerah maupun pembangunan antardaerah.

Pembangunan daerah sebagai bagian intergral dari pembangunan Nasional dilaksanakan berdasarkan prinsip otonomi daerah dan pengaturan sumber daya Nasional yang memberikan kesempatan bagi peningkatan demokrasi dan kinerja daerah untuk meningkatkan kesejahteraan masyarakat. Dan dengan adanya otonomi daerah, memberikan peluang bagi setiap daerah untuk mengembangkandaerahnya masing-masing, sesuai dengan kondisi dankeadaan jumlah penduduk,geografis, luas wilayah dan potensi ekonomi daerah yang relatif berbeda antaradaerah yang satu dengan daerah lainnya maka pengaturan biaya operasionaldisesuaikan dengan kondisi keuangan daerah, khususnya berdasarkan PendapatanAsli Daerah (PAD) dan tetap memperhatikan prinsip efiensi, efektivitas,kehematan dan dapat dipertanggung jawabkan. Pemerintah dalam melakukanperencanaan pembangunan seharusnya dilakukan dengan baik, tepat sasaran danakurat, upaya pembangunan yang terencana dilakukan untuk mencapai tujuanpembangunan yang diharapkan. Lebih jauh lagi berarti perencanaan yang tepat sesuai dengan kondisi di suatu wilayah menjadi syarat mutlak dilakukannya usaha pembangunan.

Selain itu, ada 3 alasan utama mengapa perencanaan pembangunan masih banyak digunakan di negara berkembang seperti Indonesia, yaitu adalah Pertama, karena mekanisme pasar belum berjalan secara sempurna ,maka kondisi masyarakat banyak yang masih sangat terbelakang tingkat pendidikannya menyebabkan mereka belum mampu bersaing dengan golongan yang sudah maju dan mapan. Di samping itu, informasi belum tersebar secara 
merata ke seluruh tempat karena masih banyak daerah yang terisolir karena keterbatasan prasarana dan sarana perhubungan. Dalam hal ini, campur tangan pemerintah yang dilakukan secara terencana menjadi sangat penting dan menentukan terlaksananya proses pembangunan secara baik. Kedua, karena adanya ketidakpastian masa datang sehingga perlu disusun perencanaan pembangunan untuk mengantisipasi kemungkinan situasi buruk yang mungkin timbul di kemudian hari berikut tindakan dan kebijakan preventif yang perlu dilakukan sebelumnya. Dan ketiga, karena Untuk dapat memberikan arahan dan koordinasi yang lebih baik terhadap para pelaku pembangunan, baik di kalangan pemerintah, swasta maupun masyarakat secara keseluruhan sehingga dalam jangka panjang akan terwujud proses pembangunan yang terpadu, bersinergi, dan saling menunjang satu sama lainnya (Sjafrizal, 2015: 6).

Tujuan utama dari pembangunan daerah adalah meningkatkan kesejahterakan Masyarakat daerah tersebut, dan untuk menwujudkan tujuan daripembangunan tersebut harus melalui tahapan pembangunan yang sejalan dengan kebutuhan dan tuntutan. Pemerintah pun membuat suatu pembagian pada perencanaan pembangunan nasional yang tertuang pada Undang-Undang Nomor 25 Tahun 2004 tentang Sistem Perencanaan Pembangunan Nasional dibagi menjadi Renacana Pembangunan Jangka Panjang, Rencana Pembangunan Jangka Menengah, Rencana Pembangunan Tahunan atau Pendek. Dan dari Undang- Undang ini terdapat bagian penting dari perencanaan wilayah yaitu Rencana Pembangunan Daerah yaitu terdiri dari Rencana Pembangunan Jangka Panjang Daerah (RPJPD), Rencana Pembangunan Jangka Menengah Daerah (RPJMD) dan Rencana Kerja Pemerintah Daerah (RKPD) serta Rencana Strategis Satuan Kerja Perangkat Daerah (Renstra-SKPD) dan Rencana Kerja Satuan Kerja Perangkat Daerah (Renja-SKPD) sebagai kelengkapannya.

Merujuk pada tahapan Rencana Pembangunan Jangka Panjang Nasional (RPJPN) 2005-2025 yang telah ditetapkan, maka tahapan prioritas utama dan strategi RPJMD Kabupaten Kepulauan Anambas secara adalah RPJMD ke-1 (2011-2015) diarahkan untuk menata dan meletakkan dasar dasar pembangunan Kabupaten Kepulauan Anambas yang mandiri dan berdaya saing dengan mengoptimalkan pemanfaatan sumber daya lokal dan partisipasi masyarakat untuk meningkatkan kesejahteraan rakyat. Sesuai dengan RPJMD tersebut, namun ada beberapa permasalahan yang peneliti ketahui pada saat ini yaitu belum terbangun jembatan penghubung antar kecamatan atau antar desa padahal jembatan tersebut sudah termasuk dalam stategi dan arah kebijakan yaitu meningkatkan pembangunan 
infrastruktur pendukung ekonomi yang dapat memudahkan keterhubungan antar wilayah dan dalam rangka memperlancar implementasi atau pelaksanaan FTZ dalam programnya Pengembangan Jalan dan Jembatan (RPJM Kabupaten Anambas), dan juga mengenai fasilitas kesehatan yang belum merata baik dari sisi infrastuktur maupun penunjangnya.

Hal ini termasuk dalam Startegi dan Arah Kebijakan yaitu Meningkatkan sarana prasarana di bidang kesehatan agar masyarakat bias mendapatkan layanan terbaik untuk mendukung kesehatan yang optimal, Dandalam Strategi dan Arah Kebijakan yaitu pengembangan pariwisata bahari danolahraga air secara terpadu dan berkelanjutan dengan Program Pengembangan Destinasi Wisatas tapi sampai sekarang potensi wisata yang belum digarap dengan baik dari pemerintah maupun dari masyarakat atau penduduk sekitar, Lalu maraknya illegal logging (Pohon) dan illegal minning (pasir) dan serta buruknya system drainase yang dapat meningkatkan menyebabkan banjir seperti yang diketahui pada bulan Januari tahun 2017 telah terjadi banjir yang terjadi hampir kurang lebih seminggu.

\section{METODE}

\section{Jenis penelitian}

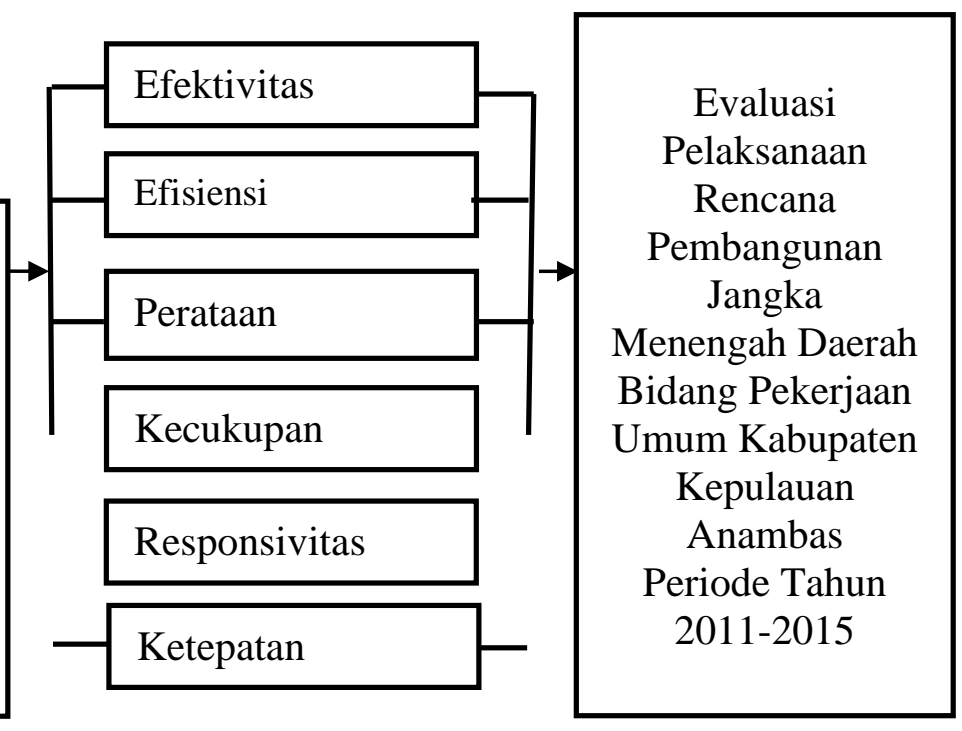

Gambar 1. Alur berpikir

Metode penelitian yang digunakan dalam penelitian ini adalah pendekatan kualitatif dengan tipe penelitian deskriptif. Strauss dan Cobin dalam buku Metode Penelitian Kualitatif mengemukakan bahwa penelitian kualitatif adalah penelitian adalah penelitian yang 
menghasilkan penemuan-penemuan yang tidak dapat dicapai dengan menggunakan prosedur stastik atau dengan cara pengukuran21. Bungin dan Creswell dalam buku Metode Penelitian Kualitatif, metode kualitatif deskriptif merupakan jenis metode kulitatif yang paling banyak dipengaruhi oleh pandangan kuantitatif (Tresiana, 2013: 14).

Penelitian ini akan berisi kutipan-kutipan data yang diperoleh peneliti dari informan untuk memberikan informasi yang menggambarkan penyajian laporan tersebut. Laporan tersebut dapat berasal dari naskah wawancara, catatan-catatan, foto, dokumen pribadi, catatan atau memo, dan dokumen resmi lainnya. Pada penulisan penelitian, peneliti menganalisis data tersebut dan sejauh mungkin menggambarkan sebagaimana aslinya. Melalui pendekatan kualitatif ini, data dan informasi diterjemahkan dan diinterpretasikan sedemikian rupa sehingga realita mengenai pelaksanaan rencana pembangunan jangka menengah daerah di Kabupaten Kepulauan Anambas dapat terungkap sebagaimana yang diinginkan.

\section{Lokasi Penelitian}

Lokasi Penelitian yaitu berada di Kabupaten Kepulauan Anambas, Kepuluan Riau. Dengan fokus penelitian yang akan di Badan Penelitian dan Pengembangan Perencanaan Daerah Kabupaten Kepulauan Anambas yang dulu bernama Badan Perencanaan Pembangunana Daerah dan beberapa Instansi Pemerintahan. Lokasi ini dipilih oleh peneliti karena Kabupaten Kepulauan Anambas adalah Kepulauan Baru di Kepulauan Riau dan baru merintis pembangunannya dan dalam hal ini Rencana Pembangunan Jangka Menengah Daerah memiliki peran penting, maka daripada itu peneliti ingin mengevaluasi Pelaksanaan tersebut.

\section{Sumber Data}

Dalam penelitian ini, data yang akan diperoleh dari dua sumber,yaitu:

\section{a. Data Primer}

Data yang di peroleh secara langsung dilapangan dengan sumber data adalah responden yang dijadikan sampel, serta pihakpihak terkait yang dianggap relevan dan memahami permasalahan yang ingin diungkapkan dalam penelitian. Data primer diperoleh langsung dari sumber asalnya, data primer diperoleh melalui wawancara yaitu mengadakan wawancara dengan informan yang bertujuan untuk menggali informasi tentang berbagai aspek yang berhubungan dengan permasalahan penelitian. 
b. Data Sekunder

Data penelitian yang di peroleh dari Instansi terkait, berupa dokumen-dokumen, laporan laporan dan buku-buku serta hasil penelitian ilmiah yang di anggap relevan dengan masalah dan tujuan penelitian.

Tabel 2. Populasi dan Sampel

\begin{tabular}{|c|c|c|c|}
\hline No. & Nama & Instansi & Jabatan \\
\hline 1. & Andiguna Kurniawan, ST & $\begin{array}{l}\text { Badan Penelitian } \\
\text { Pembangunan dan } \\
\text { Perencanaan Daerah }\end{array}$ & $\begin{array}{c}\text { Kepala Bidang } \\
\text { Infrastruktur dan } \\
\text { Pengembangan Wilayah }\end{array}$ \\
\hline 2. & Dewi Andya Sari, ST & BPPPD & $\begin{array}{c}\text { Kepala SubBagian } \\
\text { LitBang }\end{array}$ \\
\hline 3. & Jumardi, ST.,M.M & BPPPD & Staff \\
\hline 4. & Helena, S.E & BPPPD & Staff \\
\hline 5. & Bima Widyatmoko, S.Pi & BPPPD & Staff \\
\hline 6. & Khairul Nazri & $\begin{array}{c}\text { Dinas Pekerjaan Umum } \\
\text { Penataan Ruang dan } \\
\text { Kawasan Pemukiman }\end{array}$ & Kepala Bidang \\
\hline 7. & Budi Pratama, S.T & DPUPRKP & Staff \\
\hline 8. & Hera Putra Wicaksana & DPUPRKP & Staff \\
\hline 9. & Syamsuherman. S,Pi & DPUPRKP & $\begin{array}{c}\text { Kepala Bidang } \\
\text { Pemberdayaan Nelayan }\end{array}$ \\
\hline 10. & Yusnadi, S.P & DPUPRKP & Sekretaris \\
\hline 11. & Sucipnoriadi, S.H & DPUPRKP & Staff \\
\hline 12. & Ika Dewi Prasasti, S.Pi & DPUPRKP & Staff \\
\hline 13. & Khamid & Masyarakat & Petani \\
\hline 14. & Aliaman & Masyarakat & Nelayan \\
\hline 15. & Razilah & Masyarakat & Nelayan \\
\hline 16. & Maryadi & Masyarakat & Petani \\
\hline 17. & Suha & Masyarakat & Wiraswasta \\
\hline
\end{tabular}

\section{PEMBAHASAN}

\section{Efektivitas}

Efektifitas yaitu pencapaian keberhasilan dalam mencapai tujuan dari program yang telah ditetapkan oleh pemerintahan Kabupaten Kepulauan Anambas dalam Rencana Pembangunan Jangka Menengah Daerah dalam bidang urusan pekerjaan umum Periode Tahun 2011-2015. Dalam Efektifitas ini mempunya sub-indikator, yaitu :

\section{Tujuan}

Dalam subIndikator tujuan dari RPJMD dalam bidang urusan pekerjaan umum ini adalah dalam pelaksanaan sudah dilaksanakan oleh dinas yang terkait yaitu dinas pekerjaan 
umum penataan ruang dan kawasan pemukiman tetapi tujuan dari RPJMD tersebut belum terealisasi karena kendala-kendala yang ada, seperti yang dikatakan oleh Bapak Andiguna Kurniawan, ST selaku kepala bidang Infrastruktur BALITBANGPEDA tingkat keberhasilan dari RPJMD kurang lebih hanya $85 \%$, jadi masih ada $15 \%$ yang tidak terlaksanakan, yang salah satunya adalah bidang urusan pekerjaan umum yaitu terbangunnya dan beroperasinya jembatan antar pulau yang tidak terlaksanakan dan terbangun dan ketersedian perkantoran yang belum terpenuhi. Jadi tujuan dari rencana pembangunan jangka menengah daerah bidang urusan pekerjaan umum belum sepenuhnya tercapai karena adanya kendala dalam factor biaya, dan faktor lainnya.

\section{Program}

Terdapat lima program pada Bidang Urusan Pekerjaan Umumyang diamanatkan oleh RPJMD, meliputi:

1) Program pembangunan jalan dan jembatan.

2) Pengembangan dan Pengelolaan Jaringan Irigasi, Rawa dan Jaringan Pengairan Lainnya.

3) Pengembangan, Pengelolaan, dan Konservasi Sungai, Danau danSumber Daya Air Lainnya.

4) Pengembangan Kinerja Pengelolaan Air Minum dan Air Limbah.

5) Pengembangan Wilayah Strategis dan Cepat Tumbuh.

\section{Efisiensi}

Efiensi dalam RPJMD merupakan penggunaan biaya yang seminimnya atauy secukupnya tetapi pencapaiannya yang efektif. Dan Dana Pendapatan Daerah di Tahun 20112015, selama jangka waktu tahun tersebut rencana pendapatan yang ditargetkan sebesar Rp.5.403.928.880.947,79 (lima triliyun empat ratus tiga milyar Sembilan ratus dua puluh delpan juta delapan ratus delapan puluh ribu Sembilan ratus empat puluh tujuh koma tujuh puluh sembilan rupiah) dan baru terealisasi sebesar Rp.4.584.462.198.319,00 (empat triliyun lima ratus delapan puluh empat milyar empat ratus enam puluh dua juta serratus sembilan puluh delapan ribu tiga ratus sembilan belas rupiah) dengan ratarata realisasi pendapatan daerah sebesar $84,83 \%$ dari yang telah direncanakan/ditargetkan. Pendapatan Daerah Kabupaten Kepulauan Anambas periode 2010-2015 masih tergantung dari dana perimbangan 
berupa dana bagi hasil pajak, dana bagi hasil bukan pajak (SDA), Dana Alokasi Umum (DAU) dan Dana Alokasi Khusus (DAK) serta dana penyesuaian.

\section{Biaya}

Biaya merupakan hal paling penting dalam pelaksanaansebuah program. Dalam RPJMD biaya untuk program berasal dariAnggaran Pendapatan Belanja Daerah (APBD). Tetapi RPJMD ditahun 2011-2015 tersebut APBD pada saat itu terjadi defisit danPemerintah pun menutupi dengan Pembiayaan Daerah.Anggaran pada tahun 2011-2015 tersebut sesuai dengan hasilpenelitian secara wawancara, bahwa anggaran kurang dikarenakanuntuk mengaji honorer yang bekerja di kabupaten kepulauan Anambas,dikarenakan pada tahun tersebut kepala daerah menerima honoreruntuk mengurangi pengganguran didaerah tersebut. Dinas PekerjaanUmum Kabupaten Kepulauan Anambas, melaksanakan 5 (lima)

program dan 5 (lima) kegiatan dengan total anggaran sebesarRp.9.007.842.707,28 dan realisasi keuangan adalah sebesarRp.2.161.705.624,55 atau dengan capaian keuangan 24\%, denganuraian sebagai berikut:

1) Program Peningkatan Sarana dan Prasarana Aparatur Pemerintah.Program ini didukung 1 (satu) kegiatan yaitu, PembangunanGedung Kantor dengan anggaran sebesar Rp.4.359.300.000,00 danrealisasi keuangan Rp.0,00 atau dengan capaian keuangan $0,00 \%$.

2) Program Pengembangan dan Pengelolaan Irigasi, Rawa danJaringan Pengairan Lainnya. Program ini didukung 1 (satu)kegiatan yaitu, Pembangunan Jaringan Air Bersih/Minum dengananggaran sebesar Rp.570.000.000,00 dan realisasi keuanganRp.0,00 atau dengan capaian keuangan 0,00\%.

3) Program Pengembangan Kinerja Pengelolaan Air Minum dan AirLimbah.Program ini didukung 1 (satu) kegiatan yaitu,Pengembangan Sistem Distribusi Air Minum dengan anggaransebesar Rp.475.700.000,00 dan realisasi keuangan Rp.0,00 ataudengan capaian keuangan $0,00 \%$.

4) Program Pengembangan Jalan dan Jembatan.Program ini didukung1 (satu) kegiatan yaitu, Pengembangan Jalan dengan anggaransebesar Rp.2.161.705.624,55 dan realisasi keuanganRp.2.161.705.624,55 atau dengan capaian keuangan 100\%.

5) Program Rehabilitasi/Pemeliharaan Jalan dan Jembatan. Programini didukung 1 (satu) kegiatan yaitu, Rehabilitasi/PemeliharaanJalan dengan anggaran sebesar 
Rp.1.441.137.082,73 dan realisasikeuangan Rp.0,00 atau dengan capaian keuangan $0,00 \%$.

\section{Kecukupan}

Kecukupan dalam kebijakan publik dapat dikatakan tujuan yang telah dicapai sudah dirasakan mencukupi dalam berbagai hal. Kecukupan dalam program dan kegiatan RPJMD adalah program dan kegiatan yang telah direncanakan sudah cukup atau masih belum cukup untuk tujuan dari RPJMD tersebut.

a. Nilai

Nilai merupakan alat yang menunjukkan alasan dasar bahwapelaksanaan atau keadaan akhir tertentu sudah sesuai atau masihkurang dan/atau tidak sesuai dengan apa yang diinginkan. Nilai dalamRencana Pembangunan Menengah Daerah yaitu program ataukegiatannya sudah memiliki nilai cukup atau masih belum cukupberdasarkan dokumen perencanaan RPJMD itu sendiri. Peneliti melihat, Kecukupan dalam Rencana PembangunanJangka Menenengah Daerah Kabupaten Kepulauan Anambas Tahun2011-2015 dengan sub-indikatornya yaitu Nilai adalah bahwa programdan kegiatan yang telah dilaksanakan di tahun 2011-2015 tersebutmasih belum cukup untuk membangun Kabupaten KepulauanAnambas, karena masih ada beberapa program didalam RPJMD tahun2011-2015 yang belum dilaksanakan dan pada RPJMD tahun kedua iniatau Tahun 2016-2020 juga belum diteralisasikan, sepertipembangunan jembatan antar pulau, beroperasinya rumah sakit dikecamatan Tarempa. Jadi program yang belum cukup ini harus ditinjaukembali oleh pemerintah untuk dibuat program baru atau memakaiprogram yang lama tetapi sistem yang diubah

\section{Perataan}

Perataan dalam hal ini bisa diartikan sebagai adil dalam pembagian sesuatu hal, agar tidak ada rasa kecemburuan salah satu pihak yangmenerima. Kebijakan yang berorientasi pada perataan adalah kebijakanyang akibatnya atau usaha secara adil didistribusikan. Suatu programtertentu mungkin dapat efektif, efisien, dan mencukupi apabila biayamanfaatmerata. Kunci dari perataan yaitu keadilan atau kewajaran. Dalampembuatan program dalam suatu daerah harusnya merata disetiap tempatdalam suatu daerah tersebut. Begitu pun dengan 
RPJMD KabupatenKepulauan Anambas apakah dalam programnya merata disetiap daerahnyaatau tidak.

\section{Responsivitas}

Merupakan tanggapan sasaran kebijakan publik atas penerapansuatu kebijakan. Responsivitas RPJMD ini berasal dari masyarakatpendudukan anambas sebagai penerima program yang telah dibuattersebut.

a. Tanggapan

Masyarakat Kabupaten Kepulauan Anambas sebagai penerimaKebijakan/program RPJMD pastilah mempunyai tanggapan ataurespon. Tanggapan ini bisa menjadi tanggapan baik atau buruk.Tanggapan ini pun sangat bearti dalam arti tanggapan yang dapatmembuat pemerintah akan membuat kebijakan atau programpembangunan yang lebih baik lagi.

b. Kepuasan

Kepuasan masyarakat pasti berbeda-beda, ada juga masyarakatyang puas dengan kinerja pemerintah dalam melaksanakan programdari rencana pembangunan jangka menengah daerah, sepertiterbangunnya akses jalan aspal yang rapi dari Rintis ke Temburunyang mempermudah masyarakat.

Maka menurut peneliti, untuk Responsivitas dalam subindikatorTanggapan dan Kepuasaan dalam Rencana PembangunanJangka Menengah Daerah Kabupaten Kepulauan Anambas darimasyarakat setempat adalah dari masyarakat Kepulauan KabupetenAnambas yang telah di wawancarai oleh peneliti, masyarakat kurangpaham mengenai RPJMD tersebut, tetapi masyarakat ada yang sudahpuas atas programprogram yang telah dibuat tetapi ada juga yangtidak tidak puas seperti sudah terbangunnya rumah sakit tetapi rumah sakit tersebut belum bisa dipakai sampai sekarang dan pada tahun2011-2015 belum terbangunnnya tempat pembuangan sampah (TPS)tetapi baru terbangun di Tahun 2017 awal, jadi mengenai responsivitasatas RPJMD terhadap masyarakat sebagai penerima kegiatan atau program masih belum tercapai.

\section{Ketepatan}


Ketepatan yaitu proses ini keberhasilan suatu kebijakan dapatdilihatdari tujuan kebijakan yang benar-benar tercapai berguna danbernilai padakelompok sasaran, mempunyai dampak perubahan sesuaidengan misi kebijakan tersebut. Rencana Pembangunan Jangka MenengahDaerah memiliki program dan kegiatan yang ingin dilihat apa sudah tepatdalam proses pelaksanaannya, sudah tercapai dan berguna untukmasyarakat Kabupaten Kepulauan Anambas.

\section{KESIMPULAN}

Berdasarkan hasil penelitian yang telah diuraikan sebelumnya maka peneliti menarik kesimpulan diantaranya: Pertama, Efektifitas adalah dicapainya keberhasilan dalam mencapai tujuan yang telah ditetapkan atau yang telah direncanakan. bahwasanya untuk efektifitas rencana pembangunan jangka menengah daerah Kabupaten Kepulauan Anambas pada bidang urusan pekerjaan umum tahun 2011-2015 tujuan dan programnya belum terlaksanakan sesuai dengan pedoman rencana pembangunan jangka menengah daerah karena kendala-kendala pada faktor internal maupun eksternal; Kedua, Efisiensi yaitu Rencana Pembangunan Jangka Menengah Daerah Kabupaten Kepulauan Anambas Tahun 2011-2015 dalam sub-indikator yaitu Biaya adalah untuk efiensi RPJMD tersebut bisa dibilang masihlah kurang untuk melaksanakan program-program RPJMD tersebut, biaya menjadi faktor penghambat dalam pelaksanaan RPJMD ini karena biaya yang diberikan oleh pemerintah pusat sangat sedikit daripada yang telah dianggarkan oleh pemerintah Kabupaten Kepulauan Anambas dan deficit yang terjadi pada tahun tersebut;

Ketiga, Kecukupan dalam program dan kegiatan rencana pembangunan jangka menengah daerah yang telah dibuat sudah cukup untuk membangun daerah tersebut tetapi karena tidak dilaksanakan sesuai dengam apa yang sudah direncanakan, yang menjadikan rencana pembangunan jangka menengah daerah tersebut masih belum cukup untuk membangun Kabupaten Kepulauan Anambas menjadi lebih maju lagi, walaupun program yang telah dibuat buat bagus tetapi karena kendala yang terjadi yang membuat program tersebut tidak berjalan;

Keempat, Perataan merupakan membagi sama rata atau disebut juga dengan adil. Setiap daerah pasti tidak sama kebutuhannya dan kondisi tempat yang juga berbeda yang menjadikan Program rencana pembangunan jangka menengah daerah bidang pekerjaan umum tersebut dilaksanakan tidak secara merata, karena melihat dari segi kebutuhan 
masyarakat setempat yang berbeda-beda dan kondisi daerah yang berbeda yang membuat program dan kegiatan tersebut tidak merata;

Kelima, Dalam Responsivitas, Masyarakat kabupaten Kepulauan Anambas pun menanggapi bahwa ada beberapa masyarakat yang tidak mengetahui soal apa itu Program dari RPJMD dan masyarakat pun akan mengikuti program yang dibuat oleh pemerintah. Masyarakat ada yang merasa puas dan tidak puas. Karena ada beberapa program yang dari pemerintah sudah terlaksana dengan baik seperti program untuk membuat akses jalan aspal di Tarempa; dan Keenam, Dalam Ketepatan, Rencana Pembangunan Jangka Menengah Daerah, program da kegiatan yang telah direncanakan sudah tepat untuk membangun Kabupaten Kepulauan Anambas tetapi karena beberapa factor yang menghambat, yang salah satunya adalah dari masyarakat yang kurang pengetahuan teknologi yang membuat program yang ditelah rencanakan tersebut menjadi belum tepat atau belum layak.

\section{DAFTAR PUSTAKA}

Arikunto, Suharsimi. (2013). Prosedur Penelitian Suatu Pendekatan Praktik. Jakarta : PT Rineka Cipta.

Dunn, William N. (2003). Pengantar Analisis Kebijakan Publik. Yogyakarta: Gadja Mada University Press.

Herdiansyah, Haris. (2011). Metodologi Penelitian Kualitatif. Jakarta : Salemba Humanika.

Islamy. (1997). Prinsip-prinsip Perumusan Kebijakan Negara. Jakarta : Bumi Aksara.

Kismartini. (2005). Analisis Kebijakan Publik. Jakarta. Universitas Terbuka.

Nawawi, Ismail. (2009). Publik Policy (Analisis, Strategi Advokasi Teori dan Praktek). Surabaya: PMN.

Nugroho, Riant. (2003). Kebijakan Publik, Formulasi, Implementasi dan Kebijakan. Jakarta : Gramedia.

Sjafrizal. (2015). Perencanaan Pembangunan Daerah Dalam Era Otonomi. Jakarta: Rajawali Pers.

Subarsono. (2005). Analisa Kebijakan Publik. Yogyakarta: Pustaka Pelajar.

Sugiyono. (2005). Memahami Penelitian Kualitatif. Bandung: Alfabeta. 
Suharno. (2013). Dasar-Dasar Kebijakan Publik: Kajian Proses dan Analisis Kebijakan. Yogyakarta: Penerbit Ombak.

Suharno , Edi. (2008). Analisis Kebijakan Publik. Bandung: Alfabeta.

Sulistio, Eko Budi. (2012). Buku Ajar Studi Kebijakan Publik. Bandar Lampung: Lembaga Penelitian Universitas Lampung.

Tresiana, Novita. (2013). Metode Penelitian Kualitatif. Bandar Lampung: Lembaga Penelitian Universitas lampung.

Winarno, Budi. (2005). Teori dan Proses Kebijakan Publik. Yogyakarta: Media Press.

\section{Dokumen:}

Peraturan Bupati Kepulauan Anambas Nomor 18 Tahun 2010.

Peraturan Daerah Kabupaten kepulauan Anambas Nomor 8 Tahun 2011.

Peraturan Daerah Kabupaten Kepulauan Anambas Nomor 4 Tahun 2013.

Undang-Undang Nomor 23 Tahun 2014 Tantang Pemerintahan Daerah.

\section{Internet:}

Linayati Lestari (dalam Roscoe 1975, yang dikutip Uma Sekaran,2006), Jurnal Dialektika Politik, UMRAH: Tanjung Pinang, 2006, dalam portalgaruda.org/article.php?article $=479311 \&$ val $=9441 \&$ title di unduh tanggal 27 April 2018 jam 20.15.

Profil Kabupaten Kepulauan Anamabas, lihat di http://anambaskab.go.id/profilkabupatenkepulauan-anambas, di unduh tanggal 2 Oktober 2017 